Copyright (C) 2014 by Academic Publishing House Researcher

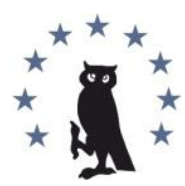

Published in the Russian Federation

European Researcher

Has been issued since 2010.

ISSN 2219-8229

E-ISSN 2224-0136

Vol. 84, No. 10-1, pp. 1747-1751, 2014

DOI: 10.13187/er.2014.84.1747

www.erjournal.ru

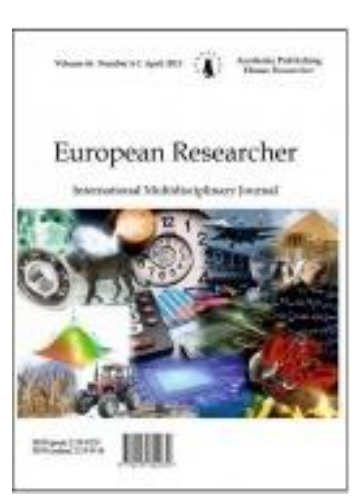

UDC 94

\title{
Sources Related to the Social-Political Movement in the Territory of the Black Sea Governorate in 1905-1907 (Based on Materials from the Archive Repositories of the Russian Federation)
}

\author{
Konstantin V. Taran
}

International Network Center for Fundamental and Applied Research, Russian Federation Laboratory of world civilizations

PhD (History)

E-mail: taran.constantin@yandex.ru

\section{Abstract}

This article examines a set of sources related to the social-political movement in the territory of the Black Sea Governorate during the First Russian Revolution (1905-1907). The author analyzes and classifies sources discovered in the archive repositories of the Russian Federation. The author concludes the article by pointing out that there is a copious set of sources covering the socialpolitical movement in the territory of the Black Sea Governorate during the First Russian Revolution. These include judicial/investigative materials, print media, documents of a personal nature by members of political organizations, memoirs, and correspondence.

Keywords: sources; social-political movement; First Russian Revolution.

\section{Введение}

Изучение деятельности общественно-политических движений начала XX в. в России и в Черноморской губернии в частности, становится необходимым сейчас, когда классический либерализм западного образца одержал относительно легкую победу над коммунистами на рубеже 1980-1990-х гг., после чего начал стремительно терять свои позиции. Одной из причин этого является недооценка уроков опыта отечественной истории. В наши дни революции происходят не так часто по сравнению с XX в., причем ученые вполне допускают, что человечество еще не раз подвергнется революционным взрывам на политической, социальной, этнической и конфессиональной почве. Это в очередной раз подтвердили события начала 2011 г., происходящие в Тунисе, Египте и Ливии, где имел место процесс обнищания масс, которые используя опыт прошлого, вышли на улицы городов, чтобы предъявить властям свои требования, а также события на Украине в 2014 году. Если недовольство народных масс существующим режимом достигает критической отметки, a у правящих кругов не хватает мудрости и гибкости, чтобы своевременно провести эффективные реформы, направленные на улучшение политического и социальноэкономического развития общества, за дело обычно берутся представители радикальных кругов.

Помимо этого актуальность темы исследования общественно-политических движений на территории Черноморья в период Первой российской революции 1905-1907 гг. 
обусловливается потребностью отечественной историографии в обращении и использовании новых методологических подходов, а также разнородных исследовательских практик, опирающихся на междисциплинарные подходы, для реконструкции и анализа важнейших исторических периодов отечественной истории с позиции современных общественных интересов. При этом региональные особенности революционных событий в большинстве случаев рассматривались в советский период, что сужало тему исследования до борьбы рабочего класса под руководством большевиков с царизмом. Такой подход сохранял значительное количество «белых пятен» истории противостояния в годы Первой российской революции. К таким «белым пятнам» можно отнести национальные и политические противоречия, которые проявились в террористических акциях и имевшем место сепаратизме.

\section{Результаты}

Источниковую базу по общественно-политическому движению на территории Черноморской губернии в 1905-1907 гг. составили разнообразные архивные документы, многие из которых впервые вводились в научный оборот.

Источники можно разделить на архивные и материалы периодической печати:

1. Архивные источники.

Архивные документы по данной проблематике обнаружены в 8 центральных, региональных и местных архивах. Для полноты картины перечислим архивохранилища и фонда представляющие интерес:

1. Государственный архив Российской Федерации (ГАРФ)

Фонд 124 - Уголовное отделение первого департамента министерства юстиции

Фонд 102 - МВД. Департамент полиции. Особый отдел. 7-е делопроизводство (наблюдательное)

2. Российский государственный военно-исторический архив (РГВИА)

Фонд 1308 - Кавказский военно-окружной суд.

Фонд 1309 - Военный прокурор Кавказского военно-окружного суда.

3. Российский государственный архив социально-политической истории (РГАСПИ)

Фонд 279 - Струве П.Б. и редакция газеты «Освобождение».

Фонд 274 - Центральный Комитет Партии социалистов-революционеров.

Фонд 673 - Архив Партии социалистов-революционеров.

4. Государственный архив Краснодарского края (ГАКК)

Фонд 252 - Войсковое правление Кубанского казачьего войска

Фонд 449 - Кубанское областное правление

Фонд 454 - Канцелярия начальника Кубанской области и наказного атамана Кубанского казачьего войска

Фонд 468 - Канцелярия черноморского губернатора

Фонд 583 - Кубанское областное жандармское управление

Фонд 584 - Канцелярия помощника начальника Кубанского областного жандармского управления

Фонд 728 - Член Новороссийского военного суда Черноморской губернии присяжный поверенный Г.Л. Корякин.

Фонд 729 - Управление начальника Сочинского округа (1905-1915).

Фонд Р-411 - Архивный отдел Управления внутренних дел Краснодарского крайисполкома

5. Центр документации новейшей истории Краснодарского края (ЦЦНИКК)

Фонд 1774-Р - Коллекция документов по истории Кубани за 1905-1990 гг.

Фонд 2830 - «Истпарт» за 1902-1921 гг. 
6. Архивный отдел администрации города Новороссийска (АОАГН)

Фонд 2 - Новороссийская городская управа 1886-1920 гг.

Фонд 4 - Новороссийская городская полиция.

Фонд 6 - Геленджикская таможенная застава (1868-1923 гг.).

Фонд 19 - Контора 17 участка службы пути.

Фонд 21 - Канцелярия начальника Черноморского округа.

7. Архивный отдел администрации города Сочи (АОАГС)

Фонд 1 - Инспектор народных училищ 2-го района Черноморской губернии.

Фонд 3 - Сочинская городская управа 1903-1919 гг.

Фонд 8 - Почтово-телеграфная контора 1878-1919 гг.

Фонд 10 - Сочинское лесничество.

Фонд Р-279 - Личный фонд Гордона К.А.

Фонд Р-282 - Коллекция документов революционного движения и Гражданской войны на Черноморье.

8. Архивный фонд музея истории города-курорта Сочи (МИГКС).

ОФ-10426. Протоколы допросов свидетелей и подозреваемых по делу о вооруженном восстании в Сочи в декабре 1905 г.

Архивные источники можно систематизировать следующим образом: судебноследственные материалы; периодическая печать; документы личного характера участников политических организаций, мемуары и переписка.

Одним из основных источников являются судебно-следственные материалы, где имеются сведения об общественно-политических движениях. Безусловно, одним из мощных информационных пластов является делопроизводственная документация особого отдела Департамента полиции (Ф. 102) и Департамента юстиции (Ф. 124), хранящиеся в Государственном архиве Российской Федерации (ГАРФ). Кроме этого, в документах из указанных фондов, содержатся донесения начальника Кубанской области, жандармских чиновников и командиров войсковых частей, телеграммы, письма и сообщения.

Наиболее ценными для исследовательской деятельности являются материалы судебно-следственных органов, политического сыска и надзора, отражавшие специальную систему документирования, т.к. характер этих учреждений соответствовал функциям, определенных российским законодательством. Здесь нужно выделить протоколы подозреваемых и свидетелей, обысков и осмотров вещественных доказательств, постановления, обвинительные акты, приговоры и др. Эти документы представлены в Российском государственном военно-историческом архиве (РГВИА) в фонде Кавказского военно-окружного суда (Ф. 1308).

Отдел истории музея истории города-курорта Сочи (МИГКС) располагает 16 томами материалов судебно-следственных органов по делу о вооруженном восстании в Сочи в декабре 1905 г. При этом нужно обратить внимание, что показания свидетелей и подозреваемых по сочинскому (МИГКС. ОПИ. ОФ-10426) и новороссийскому делу (РГВИА. Ф. 1308. Оп. 1. Д. 24177-24210) охватывают события не только октября-декабря 1905 г., но и более ранний период, т.е. примерно с начала 1900 годов, что способствует более глубокому анализу предпосылок и истоков зарождения оппозиционности общественно-политических движений к существующему режиму.

2. Материалы периодической печати

Подчиненное значение в источниковой базе занимает периодическая печать, хранящаяся в фонде периодической печати Российской государственной библиотеки (Московская область, г. Химки) и введенная в научный оборот автором. В первую очередь, это региональная пресса, например, газета «Черноморское побережье», которая выходила с 1902 г. по 9 февраля 1906 г.

Органом печати трудящихся масс являлась газета «Дубинка», редактором которой выступала Л.Д. Безходарная. Был опубликован 31 номер этой газеты в течение с 15 августа по 23 сентября 1906 г. [1] 
Кроме этого, в диссертации используются изданные мемуарные источники, среди которых работы Л.А. Яичникова [2], П.П. Джанашии [3], С.А. Бодянского [4], В.Д. Сокольского [5] и др. Авторы являются непосредственными участниками революционных событий 1905 г. в Черноморской губернии.

Определенный интерес для исследователей представляют сборники документов, в особенности тематические, выходившие, как правило, к разным юбилеям Первой российской революции 1905-1907 гг. [6-10]

\section{Заключение}

Завершая хочется отметить, что общественно-политическое движение на территории Черноморской губернии в период Первой российской революции представлено значительным перечнем источников в архивохранилищах Российской Федерации. Здесь представлены и судебно-следственные материалы, и периодическая печать, и документы личного характера участников политических организаций, и мемуары, а также переписка.

\section{Примечания:}

1. Дубинка (Екатеринодар). 1906. №2, 3, 5, 10, 11, 12, 17, 22, 24, 30.

2. Октябрь на Кубани и Черноморье. Краснодар, 1924. С. 96-100.

3. Джанашия П.П. Вооруженное восстание в Сочи в 1905 году // Каторга и ссылка: Историко-революционный сборник. Тифлис, 1925.

4. Бодянский С.А. Новороссийская республика: (Воспоминания участника событий). Прометей. М., 1969. Т. 7. С. 272-284.

5. Сокольский В.Д. Новороссийский Совет рабочих депутатов в 1905 г. // Вопросы истории, 1955, № 12.

6. Революция 1905-1907 гг. в России. Документы и материалы. М., 1955-1964.

7. 1905 год на Северном Кавказе: Сб. материалов и док. Ростов-н/Д., 1926.

8. Революционное движение на Кубани в 1905-1907 гг.: Сб. док. и материалов. Краснодар, 1956.

9. Листовки большевиков Кубани и Черноморья (1903-1920 гг.). Краснодар, 1979.

10. Осадчий И.П. Дорогой борьбы: Хроника рев. деятельности большевистских организаций Кубани и Черноморья. 1883-1920 гг. Краснодар, 1990.

\section{References:}

1. Dubinka (Ekaterinodar). 1906. №2, 3, 5, 10, 11, 12, 17, 22, 24, 30.

2. Oktyabr' na Kubani i Chernomor'e. Krasnodar, 1924. S. 96-100.

3. Dzhanashiya P.P. Vooruzhennoe vosstanie v Sochi v 1905 godu // Katorga i ssylka: Istoriko-revolyutsionnyi sbornik. Tiflis, 1925.

4. Bodyanskii S.A. Novorossiiskaya respublika: (Vospominaniya uchastnika sobytii). Prometei. M., 1969. T. 7. S. 272-284. № 12.

5. Sokol'skii V.D. Novorossiiskii Sovet rabochikh deputatov v 1905 g. // Voprosy istorii, 1955,

6. Revolyutsiya 1905-1907 gg. v Rossii. Dokumenty i materialy. M., 1955-1964.

7. 1905 god na Severnom Kavkaze: Sb. materialov i dok. Rostov-n/D., 1926.

8. Revolyutsionnoe dvizhenie na Kubani v 1905-1907 gg.: Sb. dok. i materialov. Krasnodar, 1956.

9. Listovki bol'shevikov Kubani i Chernomor'ya (1903-1920 gg.). Krasnodar, 1979.

10. Osadchii I.P. Dorogoi bor'by: Khronika rev. deyatel'nosti bol'shevistskikh organizatsii Kubani i Chernomor'ya. 1883-1920 gg. Krasnodar, 1990. 
УДК 94

\title{
Источники по общественно-политическому движению на территории Черноморской губернии в 1905-1907 гг. (на материалах архивохранилищ Российской Федерации)
}

\author{
Константин Викторович Таран
}

Международный сетевой центр фундаментальных и прикладных исследований, Российская Федерация

Лаборатория мировых цивилизаций

Кандидат исторических наук

E-mail: taran.constantin@yandex.ru

\begin{abstract}
Аннотация. В статье рассматривается круг источников по общественнополитическому движению на территории Черноморской губернии в период Первой российской революции (1905-1907 гг.). Анализируются и классифицируются источники обнаруженные в архивохранилищах Российской Федерации. В заключении автор отмечает, что общественно-политическое движение на территории Черноморской губернии в период Первой российской революции представлено значительным перечнем источников. Здесь представлены и судебно-следственные материалы, и периодическая печать, и документы личного характера участников политических организаций, и мемуары, а также переписка.

Ключевые слова: источники; общественно-политическое движение; Первая российская революция.
\end{abstract}

